\title{
Potential toxicity of pesticides in freshwater environments: Passive sampling, exposure and impacts on biofilms: the PoToMAC project
}

\author{
Christelle Margoum • Soizic Morin • Nicolas Mazzella
}

Received: 23 June 2014 / Accepted: 3 July 2014 / Published online: 11 September 2014

(C) Springer-Verlag Berlin Heidelberg 2014

The use of a large array of organic and inorganic micropollutants has been leading to an increasing pollution of surface and ground waters (Schwarzenbach et al. 2006). Headwater streams are highly dynamic systems exposed to the transport and dilution of anthropogenic inputs from agricultural land use of their watershed, where periphytic microorganisms (biofilms) play a key role in river functioning. At the basis of these ecosystems, these complex communities composed of photosynthetic organisms (both eukaryotes and cyanobacteria), bacteria, and fungi significantly contribute to primary production, nutrient cycling, and biodiversity (Lear et al. 2012). Thus, biological impairment due to pollution may cause irremediable environmental damage.

Improving pesticide assessment tools in surface waters is required to implement appropriate risk mitigation measures and ultimately contribute to the preservation or restoration of aquatic resources water quality. For this purpose, French regulations aim for a $50 \%$ reduction in the use of pesticides within 10 years. Besides, the European Water Framework Directive (WFD) (2000/60/EC) outlines a strategy for the protection and restoration of European waters, which should

\footnotetext{
Responsible editor: Philippe Garrigues

C. Margoum

Irstea, UR MALY. 5 rue de la Doua, CS 70077,

F-69626 Villeurbanne, cedex, France

e-mail: christelle.margoum@irstea.fr

S. Morin $\cdot$ N. Mazzella $(\bowtie)$

Irstea, UR EABX. 50 avenue de Verdun, F-33612 Cestas, cedex, France

e-mail: nicolas.mazzella@cemagref.fr

S. Morin

e-mail: soizic.morin@irstea.fr
}

reach a chemical and ecological 'good status' by 2015. The chemical state of French freshwater bodies is more or less extensively monitored (i.e., 5 to 12 spot samplings per year, depending on types of monitoring programs), especially for the molecules defined as 'priority substances' (2013/39/EU). To better characterize the occurrence and fate of pesticides, large efforts are made to improve analytical methods in terms of reliability and accuracy. However, the sampling step is also a crucial part of the monitoring process, and the uncertainty attached to it is still largely neglected (Allan et al. 2006). Besides, environmental quality standards (EQS) defined to protect human health or the ecosystem (2013/39/EU) is only a measure of the state of a specific environmental medium, in regard to a specific pollutant. Both improving risk evaluation procedures and characterizing pesticide effects in aquatic environments require the consideration of the interactions of substances in mixtures, such as found in the environment. The flagrant lack of knowledge in this area has been recently stressed by many researchers (Brock et al. 2006; Chèvre et al. 2006; Knauert et al. 2009).

Complementarily, the impacts of the detected substances have to be evaluated on selected living organisms or 'key biological indicators' as defined by the WFD. Biofilm, and in particular its diatom component, is one of these key compartments used in Europe to assess water quality, as an indicator of nutrient enrichment and other pressures (Coste et al. 2009; Kelly et al. 2014; Kelly et al. 2012). To date, diatom-based indices properly diagnose nutrient inputs, but fail to unequivocally assess toxic pollutions. However, the diversity of organisms in biofilms confers to this microbial community a great capacity of response to different environmental factors and thus a potential for contamination assessment. Because of their structural complexity, 
biofilms are particularly relevant in terms of ecological realism, especially for ecotoxicological approaches. The large panel of markers of toxic effects, for each component, allows distinguishing acute exposure, affecting functional descriptors (photosynthesis, enzyme activity...), from chronic impacts reflected by changes in community structure (e.g., Sabater et al. 2007).

In this context, PoToMAC project tackles some challenging issues with the development of various passive samplers, and their relevance for assessing both chronic exposure of freshwater biofilms and the potential ecotoxicity of realistic pesticide mixtures. Complementary field and laboratory approaches were developed to fulfill these objectives. In situ work was implemented in the MorcilleArdières watersheds (Beaujolais Region, France), along a gradient of contamination. Laboratory-based experiments were, besides, performed to disentangle specific effects of field observations.

Composite mixtures of organic (herbicides, insecticides, and fungicides) and inorganic (metals) pesticides are found in the watershed studied, due to intensive viticulture (Rabiet et al. 2010). Therefore, monitoring such complex contaminations required having available a wide range of specific and accurate tools to cover the broad diversity of contaminants, varied chemical properties and subsequent toxic modes of action towards the aquatic biota.

To widen the range of contaminants analyzed, metrological developments based on hydrophilic interaction liquid chromatography coupled with tandem mass spectrometric detection (HILIC-MS/MS) were dedicated to specifically and reliably quantify anionic herbicides, largely used in agriculture (Fauvelle et al. 2014). Improvements in passive sampling techniques were also performed: Fauvelle et al. (2012) investigated how various modifications in the receiving phase of the Polar Organic Chemical Integrative Sampler (POCIS) tool could expand the range of chemicals sampled from moderately hydrophilic organic compounds $\left(\log \mathrm{K}_{\mathrm{ow}}=0-4\right)$ towards more hydrophilic and ionic substances.

Furthermore, various existing passive samplers, along with POCIS, Diffusive Gradients in Thin films (DGT), and passive stir bar sorptive extraction (SBSE), were implemented together on the field and then compared with automated and spot sampling data. This in situ deployment allowed to better define their application ranges, under complex environmental conditions and high dynamics of concentration peaks (Assoumani et al. 2014).

Besides, improvements in pesticide exposure characterization in freshwater environments, PoToMAC project aimed to fill gaps related with ecological risk assessment of complex mixtures of contaminants by using biofilms. The impacts on the algal and bacterial components were assessed through descriptors of community tolerance acquisition, as well as physiological and structural impacts. This required to improve the biological indicators of toxicity and to account for the issue of multiple contaminants. Methodological improvements in toxicity testing were provided by Lambert et al. (2014), highlighting the need to standardize the conditions for measurements of acquired tolerance by phototrophic biofilms. More specifically, they evidenced the prominent influence of biofilm biomass used in PICT (Pollution-Induced Community Tolerance) tests, as well as maturation stage, whereas exposure duration had little impact. New genetic descriptors of herbicide (diuron) impact were developed by Moisset et al. (2014) for three diatom species; they proved to be early warning and more sensitive than classical growth-related endpoints. Moreover, genetic responses clearly differed between diatoms, emphasizing the inter-specific variation in tolerance to pesticides observed in field distribution records.

Finally, mixture toxicity-related issues were addressed using experimental channel designs by Foulquier et al. (2014) and Kim Tiam et al. (2014). On one hand, the relevance of passive samplers to discriminate between classes of contaminants involved in toxicity, and possible use of "model" toxic compounds to assess community induced tolerance, was investigated by Foulquier et al. They compared the ecotoxicological responses of biofilms previously exposed to filtered (dissolved compounds) or unfiltered (dissolved and particulate fractions) water to the mixtures caught by POCIS and DGT (accumulating pesticides and metals, respectively) to those obtained with the herbicide diuron and with copper. On the other hand, Kim Tiam et al. used pesticides extracted from POCIS to simulate chronic complex exposure in channel experiments. The toxicity of passive sampler extracts towards biofilms was demonstrated to be explained by the major compounds (including degradation products) identified in these devices, supporting the relevance of passive samplers for integrative environmental toxicity assessment.

\section{References}

2000/60/EC, Directive 2000/60/EC of the European Parliament and of the Council of 23 October 2000 establishing a framework for Community action in the field of water policy. OJ L 327, 22.12.2000, 1-73

2013/39/EU, Directive 2013/39/EU of the European Parliament and of the Council of 12 August 2013 amending Directives 2000/60/EC and 2008/105/EC as regards priority substances in the field of water policy

Allan IJ, Vrana B, Greenwood R, Mills GA, Knutsson J, Holmberg A, Guigues N, Fouillac A-M, Laschi S (2006) Strategic monitoring for the European Water Framework Directive. TrAC Trends Anal Chem 25:704-715

Assoumani A, Liger L, Mazzella N, Coquery M, Margoum C (2014) Field application of passive SBSE for the monitoring of pesticides in surface waters. Environ Sci Pollut Res (in this issue) 
Brock TCM, Arts GHP, Maltby L, Van den Brink PJ (2006) Aquatic risks of pesticides, ecological protection goals, and common aims in European Union legislation. Integr Environ Assess Manag 2:e20-e46

Chèvre N, Loepfe C, Singer H, Stamm C, Fenner K, Escher BI (2006) Including mixtures in the determination of water quality criteria for herbicides in surface water. Environ Sci Technol 40:426-435

Coste M, Boutry S, Tison-Rosebery J, Delmas F (2009) Improvements of the Biological Diatom Index (BDI): Description and efficiency of the new version (BDI-2006). Ecol Indic 9:621-650

Fauvelle V, Mazzella N, Delmas F, Madarassou K, Eon M, Budzinski H (2012) Use of mixed-mode ion exchange sorbent for the passive sampling of organic acids by Polar Organic Chemical Integrative Sampler (POCIS). Environ Sci Technol 46:13344-13353

Fauvelle V, Mazzella N, Morin S, Moreira S, Delest B, Budzinski H (2014) Hydrophilic interaction liquid chromatography coupled with tandem mass spectrometry for acidic herbicides and metabolites analysis in fresh water. Environ Sci Pollut Res. doi:10.1007/ s11356-014-2876-x

Foulquier A, Morin S, Dabrin A, Margoum C, Mazzella N, Pesce S (2014) Effects of mixtures of dissolved and particulate contaminants on phototrophic biofilms: new insights from a PICT approach combining toxicity tests with passive samplers and model substances. Environ Sci Pollut Res. doi:10.1007/s11356-014-3289-6

Kelly MG, Gómez-Rodríguez C, Kahlert M, Almeida SFP, Bennett C, Bottin M, Delmas F, Descy J-P, Dörflinger G, Kennedy B, Marvan P, Opatrilova L, Pardo I, Pfister P, Rosebery J, Schneider S, Vilbaste S (2012) Establishing expectations for pan-European diatom based ecological status assessments. Ecol Indic 20:177-186

Kelly M et al (2014) Comparing aspirations: Intercalibration of ecological status concepts across European lakes for littoral diatoms. Hydrobiologia 734:125-141

Kim Tiam S, Morin S, Bonet B, Guasch H, Feurtet-Mazel A, Eon M, Gonzalez P, Mazzella N (2014) Is the toxicity of pesticide mixtures on river biofilms accounted for solely by the major compounds identified? Environ Sci Pollut Res (in this issue)

Knauert S, Dawo U, Hollender J, Hommen U, Knauer K (2009) Effects of photosystem II inhibitors and their mixture on freshwater phytoplankton succession in outdoor mesocosms. Environ Toxicol Chem 28:836-845

Lambert A-S, Pesce S, Foulquier A, Gahou J, Coquery M, Dabrin A (2014) Improved short-term toxicity test protocol to assess metal tolerance in phototrophic biofilms: Toward standardization of PICT approaches. Environ Sci Pollut Res (in this issue)

Lear G, Dopheide A, Ancion PY, Roberts K, Washington V, Smith J, Lewis GD (2012) Biofilms in freshwater: their importance for the maintenance and monitoring of freshwater health. In: Lear G, Lewis GD (eds) Microbial biofilms. Current research and applications. Caister Academic Press, Norfolk, pp 129-152

Moisset S, Kim Tiam S, Feurtet-Mazel A, Morin S, Delmas F, Mazzella N, Gonzalez P (2014) Contrasted genetic responses of three freshwater diatoms under realistic exposures of diuron. Environ Sci Pollut Res (in this issue)

Rabiet M, Margoum C, Gouy V, Carluer N, Coquery M (2010) Assessing pesticide concentrations and fluxes in the stream of a small vineyard catchment—Effect of sampling frequency. Environ Pollut 158:737-748

Sabater S, Guasch H, Ricart M, Romaní A, Vidal G, Klünder C, SchmittJansen M (2007) Monitoring the effect of chemicals on biological communities. The biofilm as an interface. Anal Bioanal Chem 387: $1425-1434$

Schwarzenbach RP, Escher BI, Fenner K, Hofstetter TB, Johnson CA, von Gunten U, Wehrli B (2006) The challenge of micropollutants in aquatic systems. Science 313:1072-1077

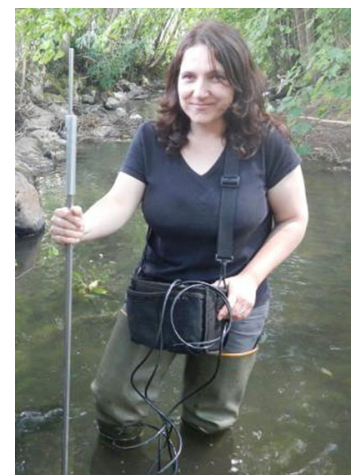

Dr. Christelle Margoum is a research engineer at the National Research Institute of Science and Technology for Environment and Agriculture (Irstea, France) in the "Freshwater Systems, Ecology and Pollution" research unit in Lyon. She has obtained her PhD in Environment and Health, University of Grenoble in 2003. Her main field of research is the study of the fate, behavior, and impact of organic contaminants, especially pesticides in aquatic ecosystems. She is specialized in the optimization of analytical methodologies for the quantification of pesticides in complex environmental matrixes based on chromatography and mass spectrometry. More recently, her research activity also includes the development of active and passive sampling tools and monitoring strategies for the evaluation of freshwater contamination. Christelle Margoum was especially in charge of the Work Package in relation with the development and methodological adjustment of a panel of passive samplers and supervised the different studies on the Morcille-Ardières Rivers during the PoToMAC project.

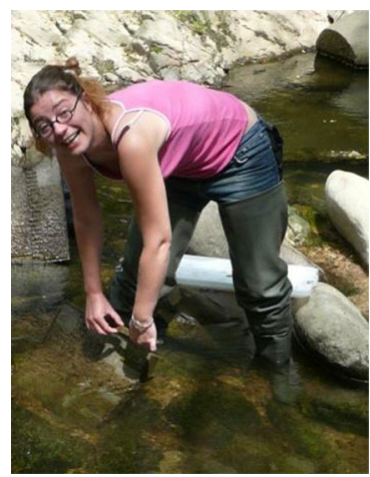

Dr. Soizic Morin is a research scientist at the National Research Institute of Science and Technology for Environment and Agriculture (Irstea) in the "Aquatic Ecosystems and Global Changes" research unit in Bordeaux. Her main interests are on periphytic communities and their responses to environmental contaminations (metals, pesticides, and emerging compounds), both in situ and through laboratory experiments (artificial streams). Her work focuses on the responses of diatoms (at different organizational levels, from the cell to the community), defining diatom species tolerances and relevant traits (e.g., cell sizes and deformities) for assessing toxic contaminations. During the PoToMAC project, Soizic Morin managed the Work Package dealing with the use of passive sampling extracts to study potential pesticide toxicity and mixture effects on periphytic communities.

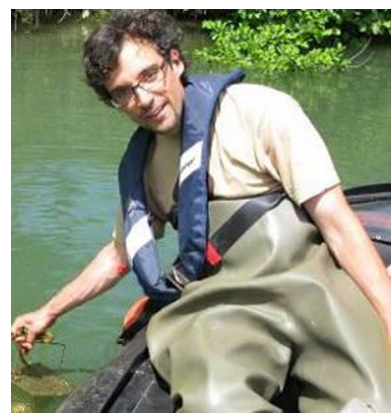

Dr. Nicolas Mazzella was recruited as a research engineer at Irstea of Bordeaux in the "Aquatic Ecosystems and Global Changes" (EABX) Research Unit since 2007. He is responsible for the water chemistry lab, a part of the EABX research unit. His lines of research include analytical and environmental chemistry, with works particularly relating to the development of passive sampling techniques (especially POCIS) so as to better understand pesticide contamination of aquatic environments and the relationship between exposure/impact on freshwater biofilms in collaboration with hydrobiologists and ecotoxicologists. Nicolas Mazzella was the coordinator of the overall PoToMAC project. 